\title{
Article/Artigo
}

\section{Degree of disability, pain levels, muscle strength, and electromyographic function in patients with Hansen's disease with common peroneal nerve damage}

\author{
Grau de incapacidade, níveis de dor, força muscular e função eletromiográfica em portadores \\ de hanseníase com lesão do nervo fibular comum
}

\section{Larissa Sales Téles Véras ${ }^{1,2,3}$, Rodrigo Gomes deSouza Vale ${ }^{2}$,Danielli Braga de Mello ${ }^{2,4}$,JoséAdail Fonseca de Castro ${ }^{1,5}$, Vicente Lima ${ }^{2}$, Kelson Nonato Gomes da Silva ${ }^{6}$, Alexis Trott ${ }^{7,8}$ and Estélio Henrique Martin Dantas ${ }^{9}$}

\section{ABSTRACT}

Introduction: This study evaluated the degree of disability, pain levels, muscle strength, and electromyographic function (RMS) in individuals with leprosy. Methods: We assessed 29 individuals with leprosy showing common peroneal nerve damage and grade 1 or 2 disability who were referred for physiotherapeutic treatment, as well as a control group of 19 healthy participants without leprosy. All subjects underwent analyses of degree of disability, electromyographic tests, voluntary muscle force, and the Visual Analog Pain Scale. Results: McNemar's test found higher levels of grade 2 of disability $(\Delta=75.9 \% ; \mathrm{p}=0.0001)$ among individuals with leprosy. The Mann-Whitney test showed greater pain levels $(\Delta=5.0 ; \mathrm{p}=0.0001)$ in patients with leprosy who had less extension strength in the right and left extensor hallucis longus muscles $(\Delta=1.28, \mathrm{p}=0.0001 ; \Delta=1.55, \mathrm{p}=0.0001$, respectively) and dorsiflexion of the right and left feet $(\Delta=1.24, \mathrm{p}=0.0001 ; \Delta=1.45, \mathrm{p}=0.0001$, respectively $)$ than control subjects. The Kruskal-Wallis test showed that the RMS score for dorsiflexion of the right $\left(\Delta=181.66 \mathrm{~m} \cdot \mathrm{s}^{-2}, \mathrm{p}=0.001\right)$ and left $\left(\Delta=102.57 \mathrm{~m} \cdot \mathrm{s}^{-2}, \mathrm{p}=0.002\right)$ feet was lower in patients with leprosy than in control subjects, but intragroup comparisons showed no difference. Conclusions: Leprosy had a negative influence on all of the study variables, indicating the need for immediate physiotherapeutic intervention in individuals with leprosy. This investigation opens perspectives for future studies that analyze leprosy treatment with physical therapeutic intervention. Keywords: Disability degree. Electromyography. Muscle strength. Pain. Peroneal nerve. Leprosy.

\section{RESUMO}

Introdução: $\mathrm{O}$ objetivo do estudo foi avaliar o grau de incapacidade, níveis de dor, força muscular e a função eletromiográfica (RMS) em indivíduos portadores de hanseníase. Métodos: A amostra foi composta de um grupo de 29 sujeitos portadores de hanseníase, apresentando lesão do nervo fibular comum e grau 1 ou 2 de incapacidade, com indicação ao tratamento fisioterapêutico, e um grupo controle de 19 indivíduos saudáveis, sem hanseníase. Os sujeitos foram submetidos à análise do grau de incapacidade, testes de eletromiografia, de força muscular voluntária e da Escala Visual Analógica (EVA) para a dor. Resultados: $\mathrm{O}$ teste de $\mathrm{McNemar}$ mostrou maior prevalência do grau dois de incapacidade $(\Delta=75,9 \% ; \mathrm{p}=0,0001)$ entre os indivíduos com hanseníase. O teste de Mann-Whitney revelou maiores níveis de dor $(\Delta=5,0 ; \mathrm{p}=0,0001)$ nos pacientes com hanseníase apresentando menores níveis de força muscular da extensão do hálux direito e esquerdo $(\Delta=1,28, \mathrm{p}=0,0001 ; \Delta=1,55, \mathrm{p}=0,0001)$ e flexão dorsal do pé direito e esquerdo $(\Delta=1,24, \mathrm{p}=0,0001 ; \Delta=1,45, \mathrm{p}=0,0001)$ do que os indivíduos sem hanseníase. O teste de Kruskal-Wallis revelou que os valores do RMS da flexão dorsal dos pés direito $\left(\Delta=181,66{\mathrm{~m} . \mathrm{s}^{-}}^{2}, \mathrm{p}=0,001\right)$ e esquerdo $\left(\Delta=102,57 \mathrm{~m} \cdot \mathrm{s}^{-2}, \mathrm{p}=0,002\right)$ apresentaram menores valores que o grupo controle em ambos os lados, mas as comparações intragrupos não mostraram diferenças. Conclusões: Conclui-se que a hanseníase altera todas as variáveis analisadas na pesquisa, indicando a necessidade de intervenção fisioterapêutica imediata nos sujeitos com Hanseníase. Esta investigação abre perspectivas de futuras pesquisas que analisem o tratamento da hanseníase com intervenção fisioterapêutica.

Palavras-chaves: Grau de incapacidade. Eletromiografia. Força muscular. Dor. Nervo fibular. Hanseníase.

1. Centro de Ciências da Saúde, Universidade Estadual do Piauí, Teresina, PI. 2. Laboratório de Biociências da Motricidade Humana, Universidade Federal do Estado do Rio de Janeiro, Rio de Janeiro, RJ. 3. Clínica Dermatológica, Hospital Getúlio Vargas, Teresina, PI. 4. Seção de Pós Graduação, Escola de Educação Física do Exército Brasileiro, Rio de Janeiro, RJ. 5. Laboratório de Doenças Parasitárias, Fundação Oswaldo Cruz, Rio de Janeiro, RJ. 6. Escola Paulista de Medicina, Universidade Federal de São Paulo, São Paulo, SP. 7. Laboratório de Aspectos Moleculares Associados a Doenças Genéticas, Universidade do Oeste de Santa Catarina, Joaçaba, SC. 8. Genética Médica, Universidade Federal do Rio Grande do Sul, Porto Alegre, RS. 9. Pós-Graduação Stricto sensu em Enfermagem e Biociências, Universidade Federal do Estado do Rio de Janeiro, Rio de Janeiro, RJ.

Address to: Dr. Alexis Trott. Lab. de Aspectos Moleculares Associados a Doenças Genéticas/UNOESC Av. Oiapoc 211, 89900-000 São Miguel do Oeste, SC, Brasil.

Phone: 5549 3631-1075; 5549 3631-1000.

e-mail: alexistrott@hotmail.com

Received in 26/07/2011

Accepted in 07/12/2011

\section{INTRODUCTION}

Leprosy, a chronic infectious-contagious disease that is endemic in certain underdeveloped areas, is caused by a bacillus with an affinity for cutaneous cells and peripheral nerves. Nerve lesions are the most important cause of disabilities and give rise to the strong stigma associated with the disease ${ }^{1}$. If Mycobacterium leprae affected only the skin, the disease would not have such an important impact on public health ${ }^{2-4}$. Leprosy is characterized by clinical, histopathological, bacteriological, and immunological manifestations ${ }^{5}$, and it is primarily transmitted via the upper respiratory tract $^{6}$.

This disease is one of the main preventable causes of disabilities in many developing countries, and is still present throughout the tropics and subtropics ${ }^{7}$. Brazil is among the most endemic countries for Hansen's disease in the world, with 37,610 new cases in $2009^{8,9}$. Despite the reduction in prevalence from 1990-2009, leprosy remains a public health problem in Brazil ${ }^{10}$. If the neural damage is not treated early and adequately, disabilities and deformities in the lower limbs may occur due to sensitivity (areas with hypoesthesia or anesthesia), motor (muscle paresis/paralysis), and autonomic (dry skin) alterations in the areas innervated by the common peroneal and posterior tibial nerves. This may prompt the appearance of stigmatizing foot drop and plantar ulcers ${ }^{11,12}$. Chronic ulcers are more common in the lower extremities than in the upper extremities ${ }^{13}$, and they appear during treatment or after hospital discharge and sometimes precede the diagnosis of leprosy ${ }^{14}$. Triggering factors predispose their emergence, such as intermittent infections, vaccination, pregnancy and puerperium, iodinecontaining medication, and physical and emotional stress ${ }^{15}$.

Muscle strength levels and electromyographic signal response can decrease in patients with leprosy due to possible nerve damage caused by the leprosy bacillus $^{16,17}$.

An examination of neural functions is necessary for adequate medical treatment, but there is still a gap in relation to the treatment of silent neuritis ${ }^{18}$. 
Delayed diagnosis and treatment are recognized risk factors for nerve damage and possible stigmatization. These often occur because infected individuals ignore symptoms such as reduced sensitivity and muscle strength or, depending on their culture, resort to traditional popular medicine for treatment ${ }^{19}$. When not diagnosed and treated early, leprosy is a chronic disease that can lead to physical incapacity ${ }^{20}$.

Shumin et al. ${ }^{21}$ and Cross $^{22}$ point to polychemotherapy and early diagnosis as preventive measures, as well as standardized treatment and diagnosis, professional qualifications, and knowledge dissemination ${ }^{23}$. Neuropathy treatment is indicated when there is clear clinical activity with symptoms and signals of evolving neuropathy, neural loss, and reversible alterations ${ }^{24}$.

Accordingly, this study aimed to evaluate electromyographic function, degree of disability, muscle strength levels, and pain in individuals with leprosy.

\section{METHODS}

\section{Sample}

We examined 29 subjects ( 19 men and 10 women) aged from 16-82 years (mean: $47.55 \pm 15.24$ years; median: 47 years), diagnosed with leprosy, who were treated at a National Health System facility in the City of Teresina, Brazil. The patients who were referred for physical therapy treatment were invited to take part in this cross-sectional cohort study. All patients were treated at the Maria Imaculada Leprosy Foundation and Lineu Araújo Hospital, both reference centers for the diagnosis and treatment of leprosy. The control group was composed of 19 healthy volunteer participants (15 men and 4 women) aged from 21-65 years (mean: $36.00 \pm 15.04$ years; median: 37 years). None of these individuals were leprosy patients nor did they exhibit any damage to the common peroneal nerve.

The following inclusion criteria were adopted: leprosy patients with damage to the common peroneal nerve, treated or undergoing treatment with polychemotherapy, with grade 1 or 2 disability, and receiving physical therapy. Patients with no disability (grade 0 ) were excluded. Grade 0 indicates no functional disability; grade 1 indicates the loss of the protective sensation on the plantar surface; and grade 2 indicates the loss of the protective sensation on the plantar surface with other complications, e.g., ulcers and traumatic injuries, claws, foot drop, absorption, or contracture of the ankle ${ }^{25}$.

Diabetic and alcoholic individuals, due to the possible presence of peripheral nerve damage ${ }^{26}$, and those presenting with poliomyelitis and stroke sequelae were excluded from the study.

The subjects gave informed written consent, in accordance with resolution 196/96 of the National Health Council and the Declaration of Helsinki ${ }^{27}$.

\section{Data collection procedures}

A simplified assessment of neural functions and complications and a formula for evaluating grades of disability standardized by the World Health Organization were used to classify grade 1 and 2 disability ${ }^{28}$.

Pain was assessed using the Visual Analog Pain Scale (VAPS), whose score ranges from zero (absence of pain) to 10 (most severe pain) ${ }^{29}$.

Right and left foot sensitivity was evaluated using a set of 6 Semmes-Weinstein nylon monofilaments (Sorri Bauru
Esthesiometer, Brazil) composed of 38-mm nylon threads of varying diameter. These produce different forces $(0.05,0.2,2.0,4.0,10.0$, and $300.0 \mathrm{~g}$ ) at specific points on each lower limb, corresponding to the tibial, peroneal, and sural nerves, and are always compared with the contralateral side. Subjects keep their eyes closed to describe whether they feel anything, using the 2.0-g filament as a reference. If this filament is not detected, protective sensitivity has changed ${ }^{10,30}$.

Muscle strength was determined using voluntary muscle testing with the Oxford scale, which ranges from 5 to 0 ( 5 = strong, $4=$ partial resistance, 3 = complete movement, 2 = partial movement, $1=$ contraction, and $0=$ paralyzed $)^{30,31}$. This test evaluates the extension strength of the right ( $\mathrm{RH})$ and left ( $\mathrm{LH}$ ) extensor hallucis longus muscles as well as the dorsiflexion of the right (RD) and left (LD) feet.

A Miotool 400 electromyograph (MIOTEC Equipamentos Biomédicos, Brazil) was used to obtain electromyographic data. This device is composed of a 4-channel system with a sampling frequency of $2000 \mathrm{~Hz}$ per channel, RAW filter, active sensors, and disposable $\mathrm{Ag} / \mathrm{AgCl}$ electrodes (diameter: $30 \mathrm{~mm}$ ). Before the electromyographic signals were recorded from the anterior tibial muscle in the control and experimental groups, hair was removed from the $\operatorname{area}^{32}$. Surface electrodes were placed on the muscle belly at one-third of the distance between the fibular head and medial malleolus ${ }^{33,34}$. Individuals were placed in a sitting position in a 45$\mathrm{cm}$ high chair with a device that immobilized both feet, impeding dorsiflexion. They were asked to execute the same movement with maximum force, showing maximum voluntary isometric contraction (MVIC). Two series of 3 MVICs were performed. Each movement lasted $5 \mathrm{~s}$, with a 3 -s interval between them, and the best of these was selected. The subjects were allowed to rest for $3 \mathrm{~min}$ between series. Data were analyzed using the average root mean square (RMS) values.

\section{Statistical analyses}

Data were analyzed using Excel and SPSS 14.0 software and presented as mean, median, standard deviation, and minimum and maximum values. Normality and homogeneity of the variance were analyzed using the Shapiro-Wilk and Levene tests, respectively. McNemar's test was applied to determine the frequency of degree of disability in the leprosy group (LG). Other variables were compared using Student's t-test for independent samples or the Mann-Whitney test when appropriate. Intergroup comparisons between $\mathrm{RMS}$ values were evaluated using the Kruskal-Wallis test, followed by Dunn's test to identify possible differences. A significance level of $\mathrm{p}<0.05$ was set for all analyses.

\section{Ethical considerations}

This study was approved by the Research Ethics Committee of the State University of Piauí, under protocol no. 120/08.

\section{RESULTS}

The LG presented with pain $(\Delta=5.0 ; \mathrm{p}=0.0001)$, while altered sensitivity was diagnosed in 24 subjects $(82.8 \%)$. The control group (CG) did not exhibit these altered characteristics.

Figure 1 presents the prevalence of grade 1 and 2 disability in the LG. A higher prevalence of individuals with grade 2 disability was found in the LG $(\Delta=75.9 \% ; \mathrm{p}=0.0001)$, with no statistically significant difference between sexes. 


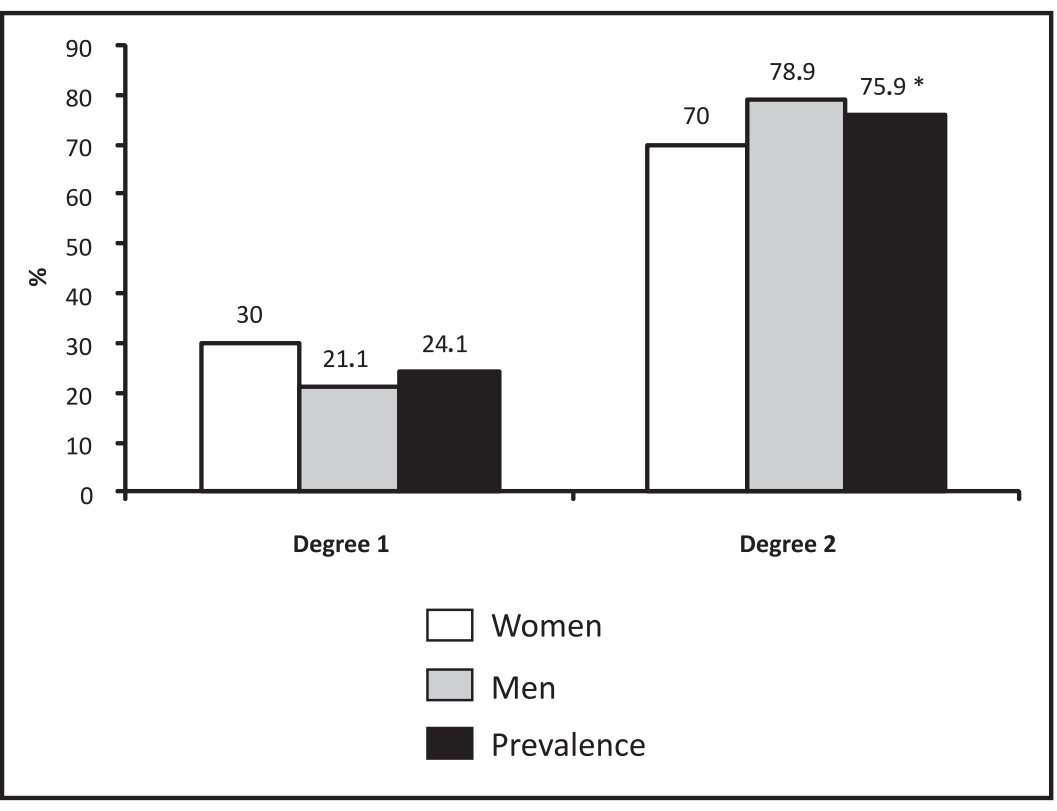

FIGURE 1 - Prevalence of the degree of disability in the leprosy group. ${ }^{*} \mathrm{p}<0.05$; degree 1 versus degree 2 .

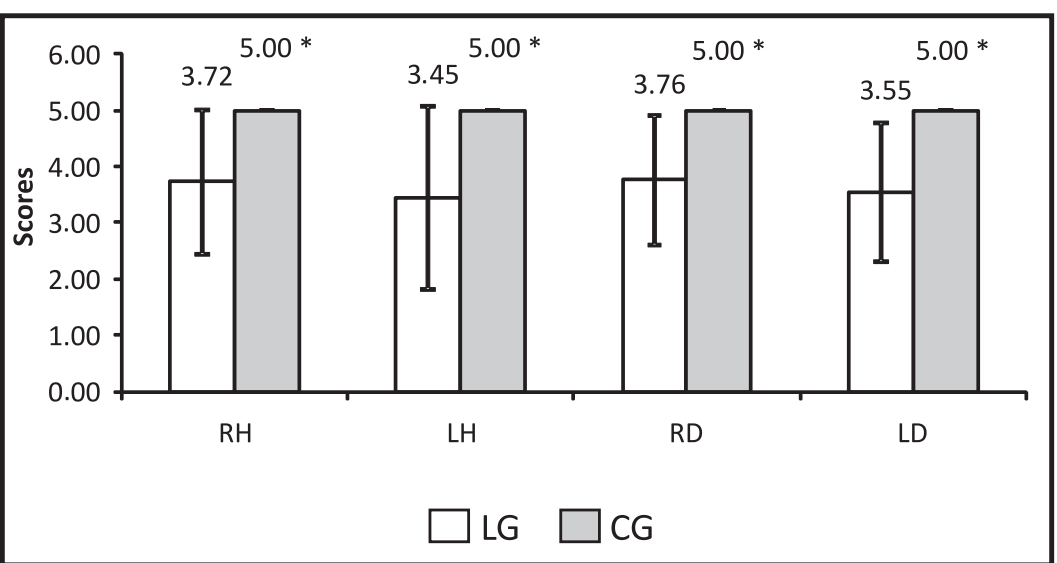

FIGURE 2 - Comparative analysis of the extension strength of the right (RH) and left (LH) extensor hallucis longus muscles and right (RD) and left (LD) dorsiflexion in the leprosy (LG) and control (CG) groups. ${ }^{*} \mathrm{p}<0.05$; LG versus CG.

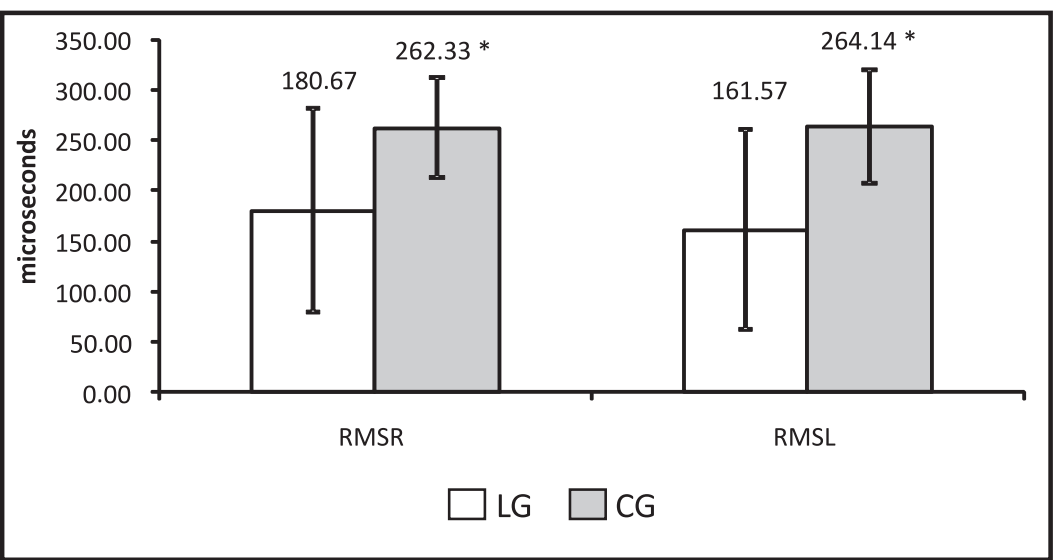

FIGURE 3 - Comparative electromyographic analysis using root mean square values during right (RMSR) and left (RMSL) dorsiflexion in the leprosy (LG) and control (CG) groups. ${ }^{*} \mathrm{p}<0.05$; LG versus CG.
Figure 2 displays the comparisons between the extension strength of the right $(\mathrm{RH})$ and left $(\mathrm{LH})$ extensor hallucis longus muscles as well as dorsiflexion of the right (RD) and left (LD) feet between the LG and CG. The LG exhibited lower extension strength in the right and left extensor hallucis longus muscles $(\Delta=1.28, \mathrm{p}=0.0001$; $\Delta=1.55, \mathrm{p}=0.0001$, respectively) and dorsiflexion of the right and left feet $(\Delta=1.24, \mathrm{p}=0.0001$; $\Delta=1.45, \mathrm{p}=0.0001$, respectively) than the CG for both movements and on both sides.

Figure 3 shows the comparison of electromyography analyzed using RMS values for right (RMSR) and left (RMSL) dorsiflexion in the LG and CG. Intragroup comparisons made between the right and left sides were not significant. The lowest levels of electromyographic signals were found in the LG. The RMSR $\left(\Delta=181.66 \mathrm{~m} \cdot \mathrm{s}^{-2}, \mathrm{p}=0.001\right)$ and RMSL $\left(\Delta=102.57 \mathrm{~m} \cdot \mathrm{s}^{-2}, \mathrm{p}=0.002\right)$ values were lower in the LG than in the CG on both sides.

\section{DIscussion}

The results of this study showed that the extension strength of the right $(\mathrm{RH})$ and left (LH) extensor hallucis longus muscles and the dorsiflexion of the right (RD) and left (LD) feet in the LG exhibited no significant intragroup differences. The LG had the lowest mean values of extension strength and dorsiflexion, which were significant when compared with the CG. The same occurred with the electromyographic signals using RMS values. However, as expected, there was always a significant difference in the RMS values between the LG and CG, with the smallest RMS values obtained in the LG.

These findings were corroborated by Wexler and Melchior ${ }^{35}$, who analyzed the palmar/plantar and dorsal sensitivity of 140 leprosy patients using 2-g monofilaments. Higher sensitivity was detected in the feet, but with no significant differences between the right and left sides. The same occurred in the LG.

Strength levels and electromyographic signal response were consistent in the LG, demonstrating that individuals with leprosy have decreased muscle strength due to possible nerve damage caused by the leprosy bacillus ${ }^{16,17}$.

The mean pain levels in the LG were $50 \%$ on the VAPS scale. The pain experienced in the LG may result from chronic inflammation, in which there is significant thickening. This is due to nerve swelling in osteoligamentous channels, the common fibular case, at knee level around the fibular neck and posterior tibial nerve in the tarsal tunnel, characterizing neuritis ${ }^{36,37}$.

The present study observed no gender-based differences in the prevalence of disability levels. However, the prevalence of disability levels seems 
to have limited value as an indicator for leprosy control when analyzed alone. The rate of new leprosy cases appears to be a better indicator. These should be analyzed in conjunction with other indicators, e.g., the rate of completed treatment, to better understand the epidemiology of this disease. Gomes et al. ${ }^{38}$ found a high (7.7\%) percentage of cases in children aged $<15$ years, a low $(5.8 \%)$ percentage of patients with undetermined diagnosis, and a substantial percentage $(21.7 \%)$ of cases with disability at diagnosis. That is, the prevalence of disability levels should be analyzed with other indicators for a better understanding of the epidemiology of Hansen's disease.

The LG showed a greater prevalence of grade 2 (75.9\%) disability, with no statistically significant difference between sexes. However, Alves et $a .^{20}$, in a study characterizing leprosy using a physical examination, reported that 100 patients, from a total of 167 patients with a diagnosis of leprosy at a dermatology service in the State of São Paulo, Brazil, exhibited some degree of physical disability, with 43 individuals ( 30 men and 13 women) showing grade 2 disability, totaling $43 \%$, excluding grade 0 . Although leprosy affects both sexes and all ages, it is more common in men ${ }^{10}$. Improved control and the application of multi-drug therapy to all patients have resulted in declining prevalence rates and a significant decrease in patients with grade 2 disability ${ }^{39}$.

Nardi et al. ${ }^{24}$ observed that individuals with leprosy in 2 Brazilian cities showed satisfactory strength and sensitivity levels in the lower limbs after polychemotherapy treatment. Neuropathy treatment is indicated when there is clear clinical activity with symptoms and signals of evolving neuropathy, neural loss detected during neurological follow-up, and reversible alterations found during nerve conduction examinations. Thus, even after discharge, all patients need a follow-up plan during polychemotherapy in order to investigate neurological losses from the reactions. Only under these situations should steroid treatment be introduced. In the present study, the LG presented with pain, while altered sensitivity was diagnosed in $82.8 \%$ of the patients, and $75.9 \%$ showed a greater prevalence of grade 2 disability, as well as a lower extension strength in the right and left extensor hallucis longus muscles and the lowest levels of electromyographic signals, which demonstrate the need for follow up with periodic evaluations as a strategy to prevent disabilities caused by neuropathy.

A randomized clinical study $(n=636)$ in patients with multibacillary leprosy initially used $40 \mathrm{mg} /$ day doses of prednisolone or prednisone and placebo, which were reduced progressively over 4 months, and showed a reduction in the number of new reactions during steroid use ${ }^{40}$. Jardim et al. ${ }^{41}$ studied paucibacillary patients $(\mathrm{n}=24)$ treated with an initial dose of $60 \mathrm{mg} /$ day. The dose was progressively reduced over 6 months, with significant improvements observed during the study period. Both studies suggest that steroid use should depend on the presence of evolving neural damage, revealed either clinically or electrophysiologically. Thus, the LG is expected to obtain similar results after the onset of treatment. Prednisolone was prescribed to some of the patients studied here, aimed at improving the neural damage, emphasizing the need for follow-up of neural functions through periodic evaluations, thereby improving the prognosis and quality of life for patients with leprosy.

In some cases, surgery is indicated. Jambeiro et al. ${ }^{42}$ assessed the results of 35 ulnar nerve decompression surgeries in 28 leprosy patients. They found that pain was reduced, muscle strength and sensitivity was increased in half of the subjects, and corticoid dosages were significantly lower. In the present study, no patient was referred for nerve decompression surgery.
In conclusion, the present study found no significant difference in RMS values within the LG and a significant difference between the LG and CG. As expected, pain levels were significant in the LG and the strength levels in this group were lower than in the CG. Leprosy was shown to alter all of the study variables, indicating the need for immediate physiotherapeutic intervention in individuals with the disease because the effective treatment of leprosy includes physical rehabilitation and the prevention of physical incapacity ${ }^{\boxplus 15}$. Thus, this investigation opens perspectives for future studies that analyze leprosy treatment with physical therapeutic intervention.

\section{CONFLICT OF INTEREST}

The authors declare that there is no conflict of interest.

\section{REFERENCES}

1. Corrêa CMJ, Ivo ML, Honer MR. Incapacidades em sujeitos com hanseníase em um centro de referência do centro-oeste brasileiro entre 2000-2002. Hansen Int 2006; 31:21-28.

2. Eidt LM. Breve história da hanseníase: sua expansão do mundo para as Américas, o Brasil e o Rio Grande do Sul e sua trajetória na saúde pública brasileira. Saude Soc 2004; $13: 76-88$.

3. Mora-Brambila AB, Trujillo-Hernandez B, Coll-Cardenas R, Huerta M, Trujillo X, Vasquez C, et al. Blink reflex, H-reflex and nerve-conduction alterations in leprosy patients. Lepr Rev 2006; 77:114-120.

4. Santos LAC, Faria L, Menezes RF. Contrapontos da história da hanseníase no Brasil: cenários de estigma e confinamento. Rev Bras Estud Popul 2008; 25:167-190.

5. Venturini J, Soares CT, Belone AFF, Barreto JA, Ura S, Lauris JRP, et al. In vitro and skin lesion cytokine profile in Brazilian patients with borderline tuberculoid and borderline lepromatous leprosy. Lepr Rev 2011; 82:25-35.

6. Queiroz JW, Dias GH, Nobre ML, Dias MS, Araújo SF, Barbosa JD, et al. Geographic Information Systems and Applied Spatial Statistics Are Efficient Tools to Study Hansen's Disease (Leprosy) and to Determine Areas of Greater Risk of Disease. Am J Trop Med Hyg 2010; 82:306-314.

7. Lasry-Levy E, Hietaharju A, Pai V, Ganapati R, Rice ASC, Haampää M, et al. Neuropathic Pain and Psychological Morbidity in Patients with Treated Leprosy: A Cross-Sectional Prevalence Study in Mumbai. PLoS Negl Trop Dis 2011; 5:e981.

8. World Health Organization. Global leprosy situation, 2010. Wkly Epidemiol Rec 2010; 85:337-348.

9. Araújo MG, Gonçalves DU, Nobre V, Ribas JGR, Carneiro-Proietti ABF, Lambertucci JR, et al. HTLV-1 associated myelopathy diagnosed during lepromatous leprosy reaction treatment: a case report. Rev Soc Bras Med Trop 2010; 43:465-466.

10. Ministério da Saúde. Vigilância em Saúde. Brasília: Ministério da Saúde; 2010.

11. Gahalaut P, Pinto J, Pai GS, Kamath J, Joshua TV. A novel treatment for plantar ulcers in leprosy: local superficial flaps. Lepr Rev 2005; 76:220-231.

12. Sharma R, Bargotra R, Gupta R, Dar HA. Comparative Study of the Effects of Wax Therapy and Foot Soaks on Dry Plantar Skin and Ulcers in Leprosy Patients. Jk Science 2005; 7:81-83.

13. Kampirapap K, Poonpracha T. Squamous Cell Carcinoma Arising in Chronic Ulcers in Leprosy. J Med Assoc Thai 2005; 88:58-61.

14. Haanpaa M, Lockwood DNJ, Hietaharju A. Neuropathic Pain in Leprosy. Lepr Rev 2004; 75:7-18.

15. Araujo MG. Hanseníase no Brasil. Rev Soc Bras Med Trop 2003; 36:373-382.

16. Werneck LC, Teive HAG, Scola RH. Muscle involvement in leprosy: study of the anterior tibial muscle in 40 patients. Arq Neuro-Psiquiatr 1999; 57:723-734.

17. Garbino JÁ, Ura S, Belone AFF, Marciano LHSM, Fleury RN. Aspectos clinicos e diagnosticos da hanseniase primariamente neural/Clinical and diagnostic aspects of the primarily neural leprosy. Hansen Int 2004; 29:124-129.

18. Van Brakel WHV, Saunderson P, Shetty V, Brandsma JW, Post E, Jellema R, et al. Workshop Report - International workshop on neuropathology in leprosy consensus report. Lepr Rev 2007; 78:416-433. 
19. Nicholls PG, Chhina N, Bro AK, Barkataki P, Kumar R, Withington SG, et al Factors contributing to delay in diagnosis and start of treatment of leprosy: analysis of help-seeking narratives in northern Bangladesh and in West Bengal, India. Lepr Rev 2005; 76:35-47.

20. Alves CJM, Barreto JA, Fogagnolo L, Contin LA, Nassif PW. Avaliação do grau de incapacidade dos pacientes com diagnóstico de hanseníase em Serviço de Dermatologia do Estado de São Paulo. Rev Soc Bras Med Trop 2010; 43:460-461.

21. Shumin C, Diangchang L, Bing L, Lin Z, Xioulu Y. Assessment of disability, social and economic situations of people affected by leprosy in Shandong Province, People's Republic of China. Lepr Rev 2003; 74:215-221.

22. Cross $\mathrm{H}$. The prevention of disability for people affected by leprosy: whose attitude needs to change? Lepr Rev 2007; 78:321-329.

23. Saunderson P. Learning to manage leprosy after 2005: preserving critical knowledge and exploiting new technology. Lepr Rev 2005; 76:2-4.

24. Nardi SMT, Paschoal VD, Zanetta DT. Freqüência de avaliações e seu impacto na prevenção das incapacidades físicas durante o tratamento dos pacientes com hanseníase. Hansen Int 2005; 30:157-166.

25. Guia para o Controle da Hanseníase. Brasília: Ministério da Saúde; 2002.

26. Garbino JA. O paciente com suspeita de hanseníase primariamente neural. Hansen Int 2007; 32:203-206.

27. World Medical Association (WMA). Declaration of Helsinki. Ethical Principles for Medical Research Involving Human Subjects. 59 ${ }^{\text {th }}$ WMA General Assembly, Seoul: WMA; 2008.

28. Ebenso J, Ebenso BE. Monitoring impairment in leprosy: choosing the appropriate tool. Lepr Rev 2007; 78:270-280

29. Dore BF, Guerra RO. Sintomatologia dolorosa e fatores associados em bailarinos profissionais. Rev Bras Med Esporte 2007; 13:77-80.

30. Roberts AE, Nicholls PG, Maddali P, Van Brakel WH. Ensuring inter-tester reliability of voluntary muscle and monofilament sensory testing in the INFIR. Lepr Rev 2007; 78:122-130.
31. Van Brakel WHV, Nicholls PG, Das L, Barkataki P, Maddali P, Lockwood DNJ, et al. The INFIR Cohort Study: assessment of sensory and motor neuropathy in leprosy at baseline. Lepr Rev 2005; 76:277-295.

32. Mello RGT, Oliveira LF, Nadal J. Anticipation mechanism in body sway control and effect of muscle fatigue. J Electromyogr Kinesiol 2007; 17:739-746.

33. Alberton CL, Silva EM, Tartaruga MP, Cadore EL, Becker ME, Brentano MA, et al Análise da reprodutibilidade do sinal eletromiográfico durante ações isométricas e dinâmicas realizadas em diferentes meios. SUBPUB. BrazJ Biomech 2007; 8:83-88.

34. Surface ElectroMyoGraphy for the Non-Invasive Assessment of Muscles (SENIAM) [Internet]. [Cited 2009 July 27]. Available from: http://www.seniam. org/.

35. Wexler R, Melchior H. Dorsal sensory impairment in hands and feet of people affected by Hansen's disease in Israel. Lepr Rev 2007; 78:362-368.

36. Duerksen F. A hanseníase e a neuropatia através da perspectiva de um cirurgião Hansen Int 2004; 29:46-50.

37. Scollard DM. The biology of nerve injury in leprosy. Lepr Rev 2008; 79:242-253.

38. Gomes CCD, Pontes MAA, Gonçalves HS, Penna GO. Perfil clínicoepidemiológico dos pacientes diagnosticados com hanseníase em um centro de referência na região nordeste do Brasil. An Bras Dermatol 2005; 80:S283-S288.

39. Brandsma JW, Schwarz RJ, Anderson AM, Herm FB. Transformation of a leprosy hospital in Nepal into a rehabilitation centre: the Green Pastures Hospital experience. Lepr Ver 2005; 76:267-276.

40. Smith WCS, Anderson AM, Withington SG, Van BrakelWH, Croft RP, Nicholls PG et al. Steroid prophylaxis for prevention of nerve function impairment in leprosy: randomised placebo controlled trial (TRIPOD 1). Brit Med J 2004; 328:1459.

41. Jardim MR, Illarramendi X, Nascimento OJM, Nery JAC, Sales AM, Sampaio EP, et al. Steroids prevent neuropathy progression. Arq Neuropsiquiatr 2007; 65:969-973.

42. Jambeiro JES, Barbosa Junior AA, Reis MG, Guedes A, Cordeiro Neto AT Assessment of ulnar neurolysis in leprous neuropathy. Acta Ortop Bras 2008; 16:207-213. 